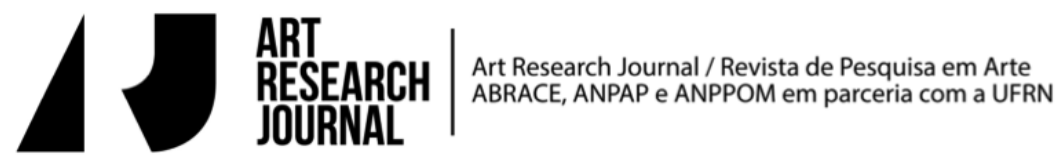

\section{Cartografia das Artes Plásticas no Recife dos anos 1980}

\author{
Maria Betânia e Silva \\ Universidade Federal de Pernambuco \\ mbsppgav@gmail.com
}

LIMA, Joana D'Arc de Sousa. Cartografias das artes plásticas no Recife dos anos 1980, 360p. Recife: Ed.Universitária da UFPE, 2014. ISBN 978-85-415-0353-2

Resultante de uma pesquisa de doutorado o livro de Joana D'Arc de Sousa Lima, publicado pela Editora Universitária da UFPE, no ano de 2014, foi intitulado Cartografia das Artes Plásticas no Recife dos anos 1980.

A autora se debruça na tessitura de uma história das artes plásticas em Pernambuco, descobrindo outro Recife, especificamente na década de 1980, período de finalização do longo período ditatorial civil-militar e de redemocratização do sistema político brasileiro.

Descobrindo pontos, conhecendo lugares, traçando caminhos Joana Lima constrói uma cartografia da cidade do Recife, abrigo de espaços de formação, produção e exibição das artes visuais, envolvendo artistas tradicionais e experimentais.

Um mapeamento minucioso, com uma atenção ímpar, tece o fio de ações realizadas por três grupos de artistas, especificamente, o ateliê Quarta Zona de Arte, o Carasparanambuco e o Formiga Sabe que Roça Come.

A vasta e plural documentação visitada e analisada como artigos jornalísticos, textos críticos, imagens fotográficas e mais de quarenta entrevistas realizadas em formato de história de vida, contribuem para o rompimento de um rótulo de "década perdida" atribuída aos anos de 1980. E, além disso, para o entendimento daquele período histórico como uma passagem, de construção de relações, percepções, tensões, descobertas individuais e coletivas. Nessa direção, os Salões de Arte da época são apresentados como espaços de atualização do processo criativo 
e das tendências múltiplas, das linguagens diversas e das diferentes gerações que compunham o meio artístico da capital pernambucana.

A autora entrecruza o local e o nacional, o indivíduo e a sociedade revelando o fio da narrativa por meio das memórias produzidas pelos entrevistados e discutindo a temática da memória. A memória individual compreendida como uma construção também por meio das experiências vividas, compartilhadas em um coletivo, com os pares, na construção de trajetórias singulares que se encontram interdependentes de outros sujeitos, de outras trajetórias, de outros grupos e coletividades. Com o intuito de inspirar a construção de imagens por meio da narrativa construída o livro foi organizado em seis cenas que focalizam os artistas, os lugares, as práticas e as obras.

Na primeira cena a cidade do Recife é apresentada em sua dinâmica artística apontando para a permanência da relação com a tradição de um lado e de outro a produção experimental.

Problematizando a escrita da crítica de arte, a segunda cena apresenta as múltiplas mudanças que o campo das artes atravessava naqueles anos.

A terceira cena verifica como os discursos da crítica de arte reverberaram no meio artístico recifense e nos modos dos fazeres e práticas artísticas.

A quarta cena apresenta a dinâmica das artes plásticas em Recife com as experiências e trajetórias identificadas nos depoimentos e documentos visitados compondo uma cartografia dos espaços de formação, produção e exibição das artes visuais na cidade. Nessa cena a estreita relação entre a arte e a política é reafirmada como um elemento de permanência histórico na cidade do Recife.

O foco nos grupos de artistas identificados, o Carasparanambuco, o Formiga Sabe que Roça Come e o Quarta Zona de Arte, está centrado na quinta cena. A cena ressalta o trabalho artístico desses grupos e identifica os artistas que integraram a chamada Geração 80 do Recife.

A última cena, a sexta, está direcionada aos textos imagéticos, narrativas pictóricas, produzidas pelos artistas do Recife. Nela, a cena, a autora discute a existência de significados construídos pelos próprios autores que ao serem interpretados pelos leitores são ressignificados. 
Fundamentado com uma vasta literatura acadêmica nacional e internacional que estabelece conexões entre conhecimentos distintos como a história, a sociologia, a história da arte, a história cultural, o livro preenche uma lacuna nas referências sobre a produção artística de um período e, mais especificamente, de um lugar singular como a cidade do Recife.

O livro narra um tempo em que se produziram esperanças para muitos dos que viveram o golpe civil-militar e, passados mais de vinte anos, puderam voltar aos espaços públicos em diversas cidades no país para reivindicar o sistema democrático, as eleições diretas para a presidência da República.

O processo de redemocratização conclamou os artistas para contribuírem com sua parcela nos movimentos diversos e reativação da vida política, que por sua vez, influenciaram os modos e fazeres artísticos e também na exibição de suas produções.

A investigação desenvolvida evidencia, entre outras descobertas, a negação de uma única Geração 80 de pintores, advindos de determinadas escolas de arte. Afirma, no entanto, a existência de diversas maneiras de produção artística no Brasil naquele período, contradizendo, assim, a visão e afirmativa redutora da crítica de arte brasileira ao classificar aquela geração como única e unidirecional, reflexo de uma narrativa historiográfica da arte oficializada e centrada, de certa forma, em experiências realizadas nas cidades do Rio de Janeiro e de São Paulo.

Por fim, a obra apresenta uma cronologia da década de 1980. Em um bloco de imagens são apresentadas fotografias de ações ambientais realizadas por artistas, do Festival de Inverno da Católica, da Mostra Internacional Art Door, de Instalações, de grupos de artistas reunidos, de matérias jornalísticas, de Arte Mural, de cenas do cotidiano da cidade, de pinturas diversas que apresentam particulares políticos e acontecimentos que borbulhavam no cotidiano vivenciado, observado e registrado pelos artistas.

O livro é um convite para um mergulho na história das artes plásticas na capital pernambucana que estava, estritamente, conectada aos acontecimentos nacionais do período, e que possuía particularidades e singularidades históricas, culturais, políticas e artísticas. Arte e política se apresentam como aspectos entrelaçados que perpassaram a história da cidade e da produção artística, revelando pontos 
cruciais, problemas sociais, contradições econômicas, relações de poder e vozes silenciadas.

Como afirma, neste livro, Antônio Paulo Resende, orientador de Joana, a visita ao passado não só assanha a memória, mas discute também tradições e referências. A velocidade dos acontecimentos nos embriaga e nos impacienta. O historiador se engana quando comemora o descartável e consolida o império do efêmero. A conversa entre mudança e permanência traz reflexões, paciências, levitações, profundidades. Quem escreve a história não se assustando com as suas cores e as suas formas, assume as andanças, com seus desvios e seus encontros surpreendentes. 